ISSN 1678-3921

Journal homepage: www.embrapa.br/pab

For manuscript submission and journal contents, access: www.scielo.br/pab

\section{Physiological parameters of cowpea treated with CaO-based particle film and subjected to water restriction}

\begin{abstract}
The objective of this work was to evaluate the effects of CaO-based particle film on the physiological parameters of cowpea (Vigna unguiculata) subjected to water restriction. Plants were subjected to two levels of soil moisture and three concentrations of the film, as follows: control, without film $+100 \%$ crop evapotranspiration (ETc); without film $+50 \% \mathrm{ETc} ; 5 \%$ $\mathrm{CaO}+50 \% \mathrm{ETc} ; 10 \% \mathrm{CaO}+50 \% \mathrm{ETc} ; 5 \% \mathrm{CaO}+100 \% \mathrm{ETc}$; and $10 \% \mathrm{CaO}+$ $100 \%$ ETc. Plants treated with $50 \%$ ETc remained stable with the application of $10 \% \mathrm{CaO}$ particle film and showed high photosynthetic assimilation of $\mathrm{CO}_{2}$ (32 $\mu \mathrm{mol} \mathrm{m} \mathrm{m}^{-2}$ ), moderate transpiration $\left(5.6 \mathrm{mmol} \mathrm{m}^{-2} \mathrm{~s}^{-1}\right)$, maintenance of chlorophyll content, and greater intrinsic water-use efficiency (IWUE, 226.65 $\left.\mu \mathrm{mol} \mathrm{mol}^{-1}\right)$ and instantaneous water-use efficiency $\left(6.06 \mu \mathrm{mol} \mathrm{mmol}^{-1}\right)$ than plants of the other treatments. Control plants and plants at $5 \% \mathrm{CaO}+50 \% \mathrm{ETc}$ showed, respectively, photosynthetic assimilation of $\mathrm{CO}_{2}$ at 15.34 and 15.94 $\mu \mathrm{mol} \mathrm{m} \mathrm{m}^{-1} \mathrm{~s}^{-1}$, transpiration at 3.51 and $3.45 \mathrm{mmol} \mathrm{m}^{-2} \mathrm{~s}^{-1}$, and IWUE at 177.7 and $198.9 \mu \mathrm{mol} \mathrm{mol}^{-1}$. The CaO-based particle film is effective in protecting bean plants subjected to water restriction.
\end{abstract}

Index terms: Vigna unguiculata, calcium, gas exchange, water deficiency.

\section{Parâmetros fisiológicos de feijão-caupi tratado com filme de partícula de $\mathrm{CaO}$ e submetido à restrição hídrica}

Resumo - O objetivo deste trabalho foi avaliar os efeitos do filme de partícula à base de $\mathrm{CaO}$ sobre os parâmetros fisiológicos do feijão-caupi (Vigna unguiculata) submetido à restrição hídrica. As plantas foram submetidas a dois níveis de umidade do solo e a três concentrações do filme, conforme a seguir: controle, sem aplicação do filme $+100 \%$ da evapotranspiração da cultura (ETc); sem filme $+50 \%$ da ETc; $5 \%$ de $\mathrm{CaO}+50 \%$ da ETc; $10 \%$ de $\mathrm{CaO}+50 \%$ da $\mathrm{ETc} ; 5 \%$ de $\mathrm{CaO}+100 \%$ da ETc; e $10 \%$ de $\mathrm{CaO}+100 \%$ da ETc. As plantas tratadas a $50 \%$ da ETc mantiveram-se estáveis com a aplicação de $10 \%$ do filme de partícula à base de $\mathrm{CaO}$ e apresentaram alta assimilação fotossintética de $\mathrm{CO}_{2}\left(32 \mu \mathrm{mol} \mathrm{m} \mathrm{m}^{-2} \mathrm{~s}^{-1}\right)$, transpiração moderada $\left(5,6 \mathrm{mmol} \mathrm{m}^{-2} \mathrm{~s}^{-1}\right)$, manutenção dos teores de clorofila, e maior eficiência intrínseca do uso da água (EIUA, 226,65 $\mu \mathrm{mol} \mathrm{mol}^{-1}$ ) e eficiência instantânea do uso da água (EUA, 6,06 $\mu \mathrm{mol} \mathrm{mmol}^{-1}$ ) do que as plantas dos outros tratamentos. As plantas-controle e as plantas tratadas a $5 \%$ de $\mathrm{CaO}+50 \%$ da ETc apresentaram, respectivamente, assimilação fotossintética de $\mathrm{CO}_{2}$ a 15,34 e $15,94 \mu \mathrm{mol} \mathrm{m}^{-2} \mathrm{~s}^{-1}$, transpiração a 3,51 e $3,45 \mathrm{mmol} \mathrm{m}^{-2} \mathrm{~s}^{-1}$, e EIUA a $177,7 \mathrm{e}$ $198,9 \mu \mathrm{mol} \mathrm{mol}^{-1}$. O filme de partícula à base de $\mathrm{CaO}$ é eficaz na proteção de plantas de feijão-caupi submetidas à restrição hídrica.

Termos para indexação: Vigna unguiculata, cálcio, trocas gasosas, deficiência hídrica. 


\section{Introduction}

The semiarid Northeastern region of Brazil is characterized by areas of shallow and stony soils, lowwater retention capacity, high evaporation, erosion potential, high temperatures, and irregularities of rainfall distribution, which are limiting factors for agriculture (Cunha et al., 2008). Some methods are used to mitigate the low availability of water resources in this region, such as the cultivation of resistant varieties (Bastos et al., 2012). Water deficit has an impact on the growth and development of the plants that causes the decrease of productivity (Boari et al., 2015) because it induces a series of morphological changes, as well as physiological, biochemical, and molecular responses of the plants.

Among these responses, photosynthesis is the primary physiological variable to be affected (Chaves, 1991), since water, the basic component of the reaction, maintains the transpiratory flow and the stomatal regulation that are essential for the entry of $\mathrm{CO}_{2}$ into the leaf mesophyll (Shellie \& King, 2013). The stomatal regulation reduces the rate of transpiration and is a common response to water restriction, as it increases the efficiency of water use by the plant (Parry et al., 2005).

Cowpea [Vigna unguiculata (L.) Walp.] is cultivated by medium and small producers in the North and Northeast of the country. Its importance is not restricted to the Brazilian territory only; it is also important in arid and semiarid zones all over the world, as their productions depend on rainfall as the only source of water supply. Cowpea is a crop that shows rusticity and adaptation to water restriction conditions, such as leaf area decrease and, consequently, low yield. Among the main causes of its low productivity is the inadequate management without the adoption technology, and water limitation (Saboya et al., 2013). To increase the productivity and reduce the production costs, it is necessary to use more adequate strategies for the irrigation management (Oliveira et al., 2011), in order to optimize the efficiency of water use. One of these strategies used is the particle film (Glenn, 2016).

The application of the particle film creates a canopy cover of the plant which increases the efficiency of water use because the particle film reflects part of the radiation, reducing the crop transpiration, as a consequence of the reduction of the pressure deficit between leaves and the air, and of the reduction of the stomatal conductance, which decrease the damage to leaves and fruit by high temperatures and solar lesions (Glenn, 2016). In addition, it has been observed in several crops the reduction of stomatal conductance and transpiration due to the application of the film, as in apple, beans, tomato, and coffee (Cantore et al., 2009; Silva et al., 2019), as well as in pomegranates, walnuts, and citrus fruit (Cantore et al., 2009; Pace et al., 2009; Weerakkody et al., 2010; Glenn, 2012; Boari et al., 2015). As in these crops, the particle film can also result in a considerable benefit to the water economy because it increases the agricultural yield of bean in cowpea crop.

The objective of this work was to evaluate the effects of the $\mathrm{CaO}$-based particle film on the physiological parameters of cowpea subjected to water restriction.

\section{Materials and Methods}

The experiment was carried out at the rural campus of the Universidade Federal de Sergipe (UFS), in the

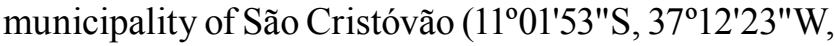
at $47 \mathrm{~m}$ altitude), in the state of Sergipe, Brazil. The soil of the site is classified as Argissolo VermelhoAmarelo (Ultisols) characteristic of the Tabuleiros Costeiros region (Oliveira et al., 2017). Seed of cowpea 'BRS Guariba', with indeterminate growth and relatively short branches, which shows resistance to lodging, heating, and water deficiency were used. This cultivar has a relatively short cycle, from 65 to 70 days (Gonçalves et al., 2009).

The cultivation was performed in the field. Climatic data were obtained from an automatic meteorological station of the Instituto Nacional de Meteorologia (Inmet), located $19 \mathrm{~km}$ from the experiment (Figure 1).

A randomized complete block design was used, with six treatments and five replicates, covering a total area of $120 \mathrm{~m}^{2}$. Experimental units had $24 \mathrm{~m}^{2}$ each, and they were formed by six rows of $5 \mathrm{~m}$ length each. The spacing used was $0.8 \times 0.1 \mathrm{~m}$, and planting was carried out by direct seeding of one seed per pit. After 15 days of sowing, the thinning was performed, leaving five plants per meter. Drip irrigation was applied. After 38 days of sowing, plants were subjected to the application of water slides corresponding to 50 and $100 \%$ repositions of the crop evapotranspiration (ETc) and, from the pre-flowering on, the particle film based 
on $\mathrm{CaO}(0.5$ and $10 \%$ calcium oxide) was applied every 10 days.

The treatments were applied as follows: a control without the application of $\mathrm{CaO}$ particle film of $\mathrm{CaO}$ + replacement of $100 \%$ ETc per unit area of leaf; no particle film of $\mathrm{CaO}$ application + replacement of $50 \%$ ETc; particle film of $\mathrm{CaO}$ application at $5 \%+50 \% \mathrm{ETc}$; particle film of $\mathrm{CaO}$ application at $5 \%+100 \% \mathrm{ETc}$; particle film of $\mathrm{CaO}$ application $10 \%+50 \% \mathrm{ETc}$; and particle film of $\mathrm{CaO}$ application at $10 \%+100 \%$ ETc. The ETc was determined as the product of the reference evapotranspiration (ETo) and the crop coefficient (Kc, in $\mathrm{mm}$ per day). Kc values were used for the different development stages of cowpea, as suggested by Ribeiro (2002). The reference evapotranspiration was calculated using the Penman-Monteith method. Daily values used for ETo determination were collected at the meteorological station.

Irrigation was applied daily by surface dripping with $0.20 \mathrm{~m}$ spacing between drippers and $1.2 \mathrm{~L}$ flow per hour. The irrigation depth to be applied to the crop was calculated by NI $=$ ETc $\times$ II, in which II was the irrigation interval (usually 1 to 3 days), and $\mathrm{TNI}=\mathrm{NI} / 0.9$, by the relation between the real, necessary irrigation (NI) and the efficiency of application, whose value is generally estimated at $90 \%$ (Mantovani et al., 2009), and the total necessary irrigation (TNI) is obtained. The irrigation time per plant was calculated by the equation $T_{i}=T N I \times A / n \times Q g$, in which: $T_{i}$ is the irrigation time in hours; $\mathrm{A}$ is the area of each plant

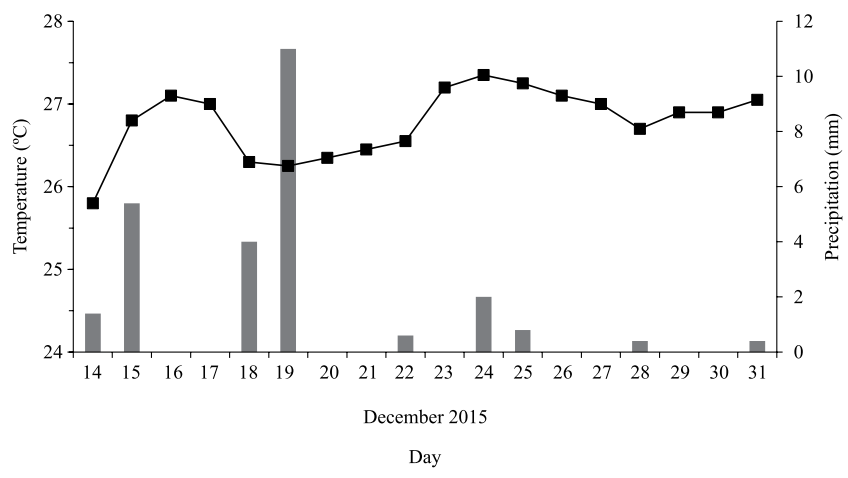

Figure 1. Daily average values of air temperature (line) and precipitation (column), from 14 to 31 December 2015, in the municipality of São Cristóvão, in the state of Sergipe, Brazil. Source: Inmet (2015). $\left(\mathrm{m}^{2}\right) ; \mathrm{n}$ is the number of drippers per plant; and $\mathrm{g}$ is the flow in the dripper (liters per hour).

The $\mathrm{CaO}$ particle film was prepared in a $25 \mathrm{~g} \mathrm{CaO}$ dilution in $500 \mathrm{~mL}$ water, to obtain the film with the concentration of $5 \% \mathrm{CaO}$, and $50 \mathrm{~g} \mathrm{CaO}$ in $500 \mathrm{~mL}$ water, to obtain the film at $10 \% \mathrm{CaO}$ concentration. The $\mathrm{CaO}$ particle film solution was applied to cowpea aerial parts from plant stage R6, by a manual medium compression sprayer, until the maturation phase, in a total of three applications.

The evaluated parameters were: gas exchange, photosynthetic $\mathrm{CO}_{2}$ assimilation per unit leaf area (A, $\left.\mu \mathrm{mol} \mathrm{m} \mathrm{m}^{-2} \mathrm{~s}^{-1}\right)$, stomatal conductance to water vapor $\left(\mathrm{g}_{\mathrm{s}}\right.$, mol m $\mathrm{m}^{-2} \mathrm{~s}^{-1}$ ), instant transpiration (E, mmol m $\left.\mathrm{m}^{-2} \mathrm{~s}^{-1}\right)$, vapor pressure deficit between leaf and air $\left(\mathrm{VPD}_{\text {leaf-air, }}\right.$ $\mathrm{kPa}$ ), the instantaneous water use efficiency (WUE): $\left.\mathrm{A} / \mathrm{E}, \mu \mathrm{mol} \mathrm{mmol}^{-1}\right)$, intrinsic water use efficiency (IWUE) $\left(\mathrm{A} / \mathrm{g}_{\mathrm{s}}, \mu \mathrm{mol} \mathrm{mol}^{-1}\right)$, and the content of chlorophylls $\mathrm{a}$ and $\mathrm{b}$.

The parameters $\mathrm{A}, \mathrm{g}_{\mathrm{s}}, \mathrm{E}$, and $\mathrm{VPD}_{\text {leaf-air }}$ were analyzed using the infrared gas analyzer (IRGA) model LI-6400 (Li-color, Biosciences Inc., Lincoln, NE, USA). The photosynthetically active radiation (PAR) was kept constant inside the chamber at 1500 $\mu \mathrm{mol} \mathrm{m} \mathrm{m}^{-2} \mathrm{~s}^{-1}$ intensity, focusing on a $2 \mathrm{~cm}^{2}$ leaf area by the artificial lighting system composed of a mixture of blue and red light emitting diodes (LEDs) coupled to the equipment. The concentration of atmospheric $\mathrm{CO}_{2}$ and the relative humidity of the chamber were around $398 \pm 2 \mu \mathrm{mol} \mathrm{mol}^{-1}$ and $60 \pm 9 \%$, respectively, which were adjusted for both adaxial and abaxial leaf analysis. The reference air was collected at approximately $2 \mathrm{~m}$ above the ground surface and homogenized in a $2 \mathrm{~L}$ gallon before reaching the leaf chamber, after which, IWUE and WUE were estimated.

The punctual measurements were performed between 7 and 9 o'clock in the morning, 24 days after the application of the treatments, in two completely expanded leaves of each plant (3rd or 4th leaves counted from the apex, positioned on opposite sides) of five plants per treatment.

The measurements of chlorophyll a and b contents of leaves were performed on the same day, and in the same leaf in which gas exchange was determined, with a portable CFL 1030 chlorophyll meter clorofiLOG (Falker, Porto Alegre, RS, Brazil).

The obtained data were subjected to the analysis of variance, and to the comparison of means by the 
test of Tukey, at 5\% probability, using of the statistical program Sisvar (Ferreira, 2011).

\section{Results and Discussion}

During the experimental period, the temperature varied from 25 to $30^{\circ} \mathrm{C}$, with an average of $28^{\circ} \mathrm{C}$, and the precipitation did not exceed $13 \mathrm{~mm}$; the relative humidity varied from 44 to $75 \%$, and the mean radiation was $2,800 \mathrm{~kJ} \mathrm{~m}^{-2}$ (Figure 1 ).

The parameters of gas exchange were influenced by water restriction and the application of the $\mathrm{CaO}$ particle film. The application of the particle film favored the photosynthetic assimilation of $\mathrm{CO}_{2}$ in the concentrations of $10 \% \mathrm{CaO}$ when the crop was irrigated with 50 and $100 \%$ of ETc, at 32 and $38 \mu \mathrm{mol}$ $\mathrm{m}^{-2} \mathrm{~s}^{-1}$ respectively (Figure 2). Furthermore, the $10 \%$ treatment with $50 \%$ of ETc was greater than the $100 \%$ of ETc control which presented $28 \mu \mathrm{mol} \mathrm{m}^{-2} \mathrm{~s}^{-1}$. Singh \& Redd, (2011) and Freitas et al. (2017), in their studies on water restriction also found similar A values for Vigna unguiculata. The stomatal conductance was reduced in all treatments with $50 \%$ ETc in comparison to the $100 \%$ ETc control, which can be attributed to water restriction that promoted the reduction of stomatal opening to decreased water loss.

The application of the particle film at $10 \% \mathrm{CaO}$ caused in the plants, even under water restriction, the maintenance of stomatal conductance and photosynthetic assimilation of $\mathrm{CO}_{2}$ higher than the control. However, the same fact was not observed for particle film at $5 \% \mathrm{CaO}$ concentration. The effect of water restriction on plants usually shows a drop of the $\mathrm{g}_{\mathrm{s}}$ to minimize water loss (Chavarria et al., 2015) and, as a consequence of this stomatic regulation, the values of the photosynthetic assimilation of $\mathrm{CO}_{2}$ are reduced. The highest $g_{s}$ values in the treatment of $10 \%$ $\mathrm{CaO}$ and $50 \%$ ETc can be attributed to the thermal equilibrium imposed by the particle film that caused the leaf temperature to become inferior to that of the control, when plants were subjected to the water restriction (Figure 3). This temperature decrease is the result of the reduction of the incident radiation absorbed by leaves, as a consequence of the film reflection, in which infrared and ultraviolet radiations were reflected (Shellie \& Glenn, 2008).

However, plants that received $5 \%$ of the film did not show the same photosynthetic performance, and they did not differ from the control with water restriction
(Figure 2). This fact indicates that this amount of $\mathrm{CaO}$ was not sufficient to reflect the excess infrared and ultraviolet radiations, which caused an increase of the temperature and the stomatal regulation occurred. Therefore, it can be seen that the efficacy of the film as a reflective antiperspirant agent was influenced by the concentration and water restriction.

The decrease of the photosynthetic assimilation of $\mathrm{CO}_{2}$ (A) values in the control treatment and in the treatment with $5 \%$ film under water restriction may also be due to the reduction of the maximum carboxylation rate of the RuBisCO (RuBP), since the reduction of photosynthesis, under water restriction conditions, may be conditioned to the limitation of rubisco activity by enzymatic inhibition factors (Parry et al., 2005), and by the reduction of the transport rate of photosynthetic electrons, which influences the regeneration capacity of RuBP (Lawlor 2009).

The beans transpiration is also a component of the energy balance that determines the leaf temperature, $\mathrm{g}_{\mathrm{s}}$, and A. In the treatment with $50 \%$ of ETc (control and $5 \%$ film), the mean transpiration value was $3.4 \mathrm{mmol}$ $\mathrm{m}^{-2} \mathrm{~s}^{-1}$ (Figure 2), which is lower than the treatment with $10 \%$ concentration $\left(5.5 \mathrm{mmol} \mathrm{m} \mathrm{m}^{-2} \mathrm{~s}^{-1}\right)$. As water becomes limiting, the transpiration is reduced, and the leaf temperature increases significantly in relation to the air temperature. With the reduction of water and transpiratory availability, it occurs an increase of the leaf temperature by the interception of solar radiation (Gontia \& Tiwari, 2008; Wang \& Gartung, 2010), in other words, the transpiration is associated with the difference in leaf-to-air temperatures, which becomes more negative as the energy from leaf to air is transferred in the form of latent heat. In beans kept at $50 \%$ ETc without the application of particle film, the leaf temperature was higher than in the other treatments (Figure 3).

The stomatal regulation of the plants subjected to water restriction resulted in less transpiration of these plants, and those in treatments with the film at $10 \%$ showed less stomatal closure and greater transpiration (inferior to the control $100 \%$ of ETc). Thus, it can be inferred that the $10 \%$ particle film promoted an efficient stomatal regulation in plants which were able to reduce, or optimize the stomatal opening and closure, a fact was also verified by other authors using kaolin as a particle film (Shellie \& Glenn 2008; Cantore et al., 2009; Boari et al., 2015; 
Boari et al., 2016). Films based on $\mathrm{CaO}$ and kaolin directly influence the photosynthetic assimilation of $\mathrm{CO}_{2}$ and the water status of plants (Shellie \& King, 2013), which makes the particle film an efficient antiperspirant (El-Khawaga, 2013).

As well as the transpiration, the $\mathrm{VPD}_{\text {leaf-air, }}$ which is also related to water restriction, showed the highest values in irrigated plants with $50 \%$ ETc $-2.97,2.91$, and 3.18 - for the control and treatments with particle film at 5 and $10 \% \mathrm{CaO}$, respectively, while in the plants with $100 \%$ of the ETc, the VPD $\mathrm{V}_{\text {leaf-air }}$ was lower (Figure 2).

Even with higher $\mathrm{VPD}_{\text {leaf-air }}$ in plants with water restriction, the $\mathrm{A} / \mathrm{g}_{\mathrm{s}}$ and $\mathrm{A} / \mathrm{E}$ ratio was higher with the particle film, which provided greater efficiency in the concentration of $10 \%$ with $50 \%$ of ETc, while the least efficient treatment was the control using $100 \% \mathrm{ETc}$ (Figure 3). The $\mathrm{A} / \mathrm{g}_{\mathrm{s}}$ ratio (IWUE), in the
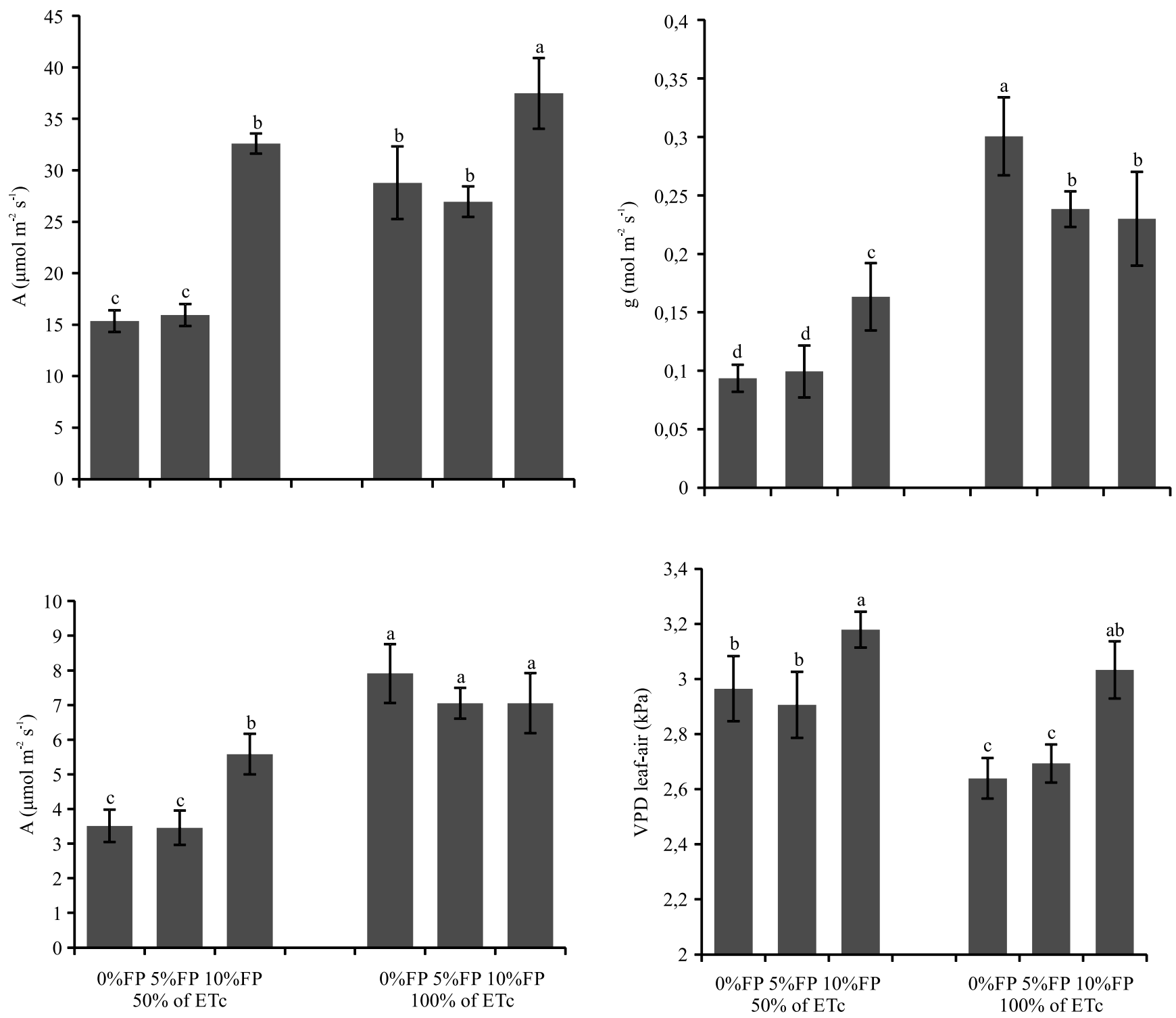

Figure 2. Assimilation of $\mathrm{CO}_{2}$ or photosynthetic rate $(\mathrm{A})$, stomatal conductance to water vapor $\left(\mathrm{g}_{\mathrm{s}}\right)$, transpiration rate to water vapor $(\mathrm{E})$, vapor pressure deficit between leaf and air $\left(\mathrm{VPD}_{\text {leaf-air, }} \mathrm{kPa}\right)$ in cowpea plants (Vigna unguiculata) subjected to ETc replacements at 50 and $100 \%$, and to treatments with pulverized $\mathrm{CaO}$-particle film (PF) at 0 , 5, and $10 \%$. Means followed by equal lowercases for different treatments do not differ, by Tuckey's test, at $5 \%$ probability. 
condition of water restriction, mainly in plants that received the film at 5 and $10 \% \mathrm{CaO}$, was an indicative of cowpea great ability to regulate the gas exchanges, reducing the stomatal conductance and, consequently, showing a greater reduction of the transpiration than in the assimilation of $\mathrm{CO}_{2}$, which produces greater water savings for each assimilated $\mathrm{CO}_{2}$ molecule. This increase was also verified in the film at $10 \%$ $\mathrm{CaO}$ with $100 \% \mathrm{ETc}$, that is, even in plants under ideal water conditions the particle film optimized the IWUE, through the partial reduction of the
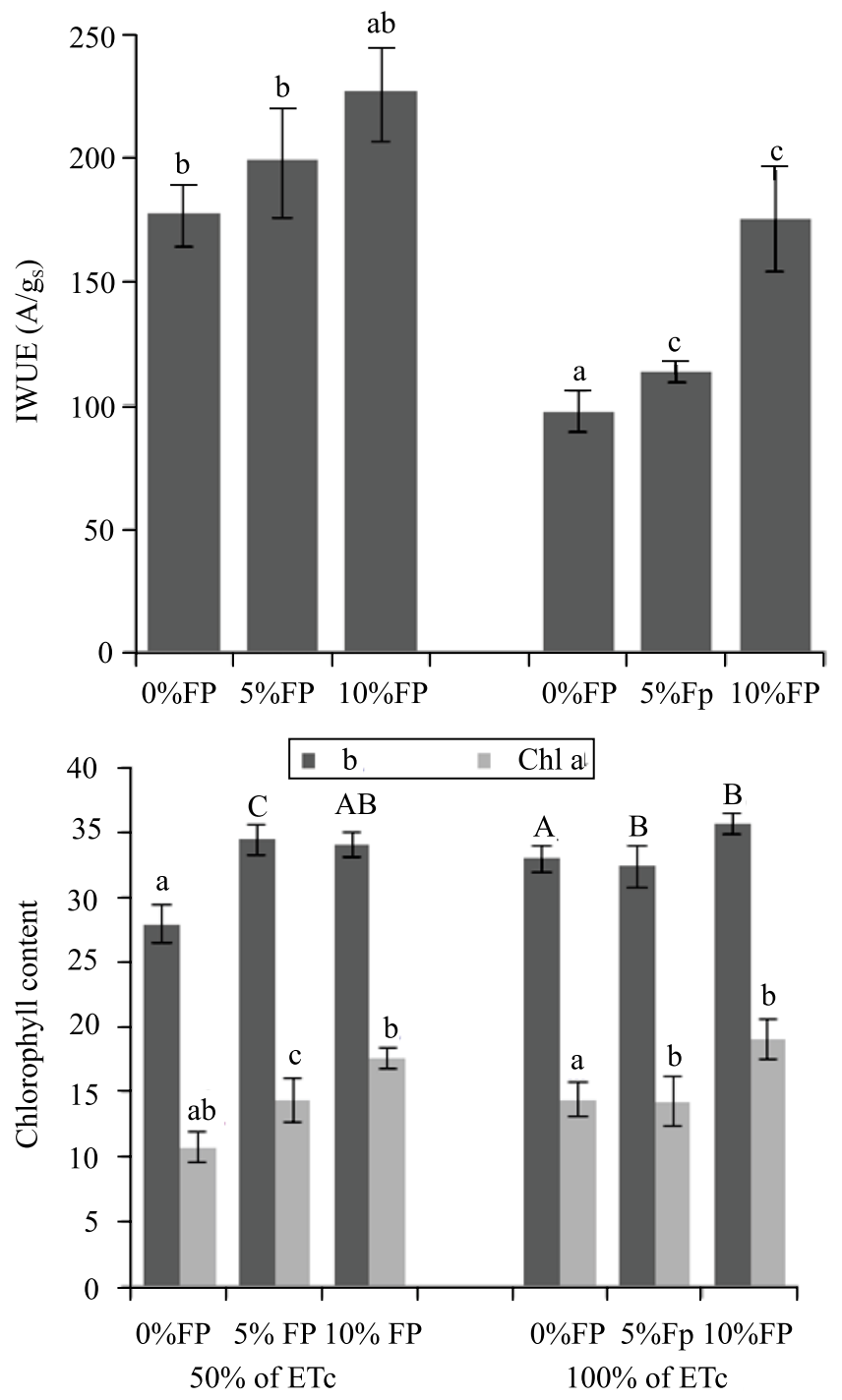

stomatal conductance that proportionally limited the transpiration more than the $\mathrm{CO}_{2}$ entry in the leaf.

It can also be considered that cowpea treated with the particle film at $10 \% \mathrm{CaO}$ and $50 \%$ ETc used water more efficiently due to the higher-average value of intrinsic water use efficiency (IWUE, 226,65 $\mu \mathrm{mol}$ $\mathrm{mol}^{-1}$ ), which is indicative that a greater amount of $\mathrm{CO}_{2}$ was absorbed, in detriment of lower-water loss, as this treatment differed from those without the application particle film (177.70 and $97.57 \mu \mathrm{mol} \mathrm{mol}{ }^{-1}$ for 50 and $100 \%$ ETc, respectively). Supposedly, the particle film
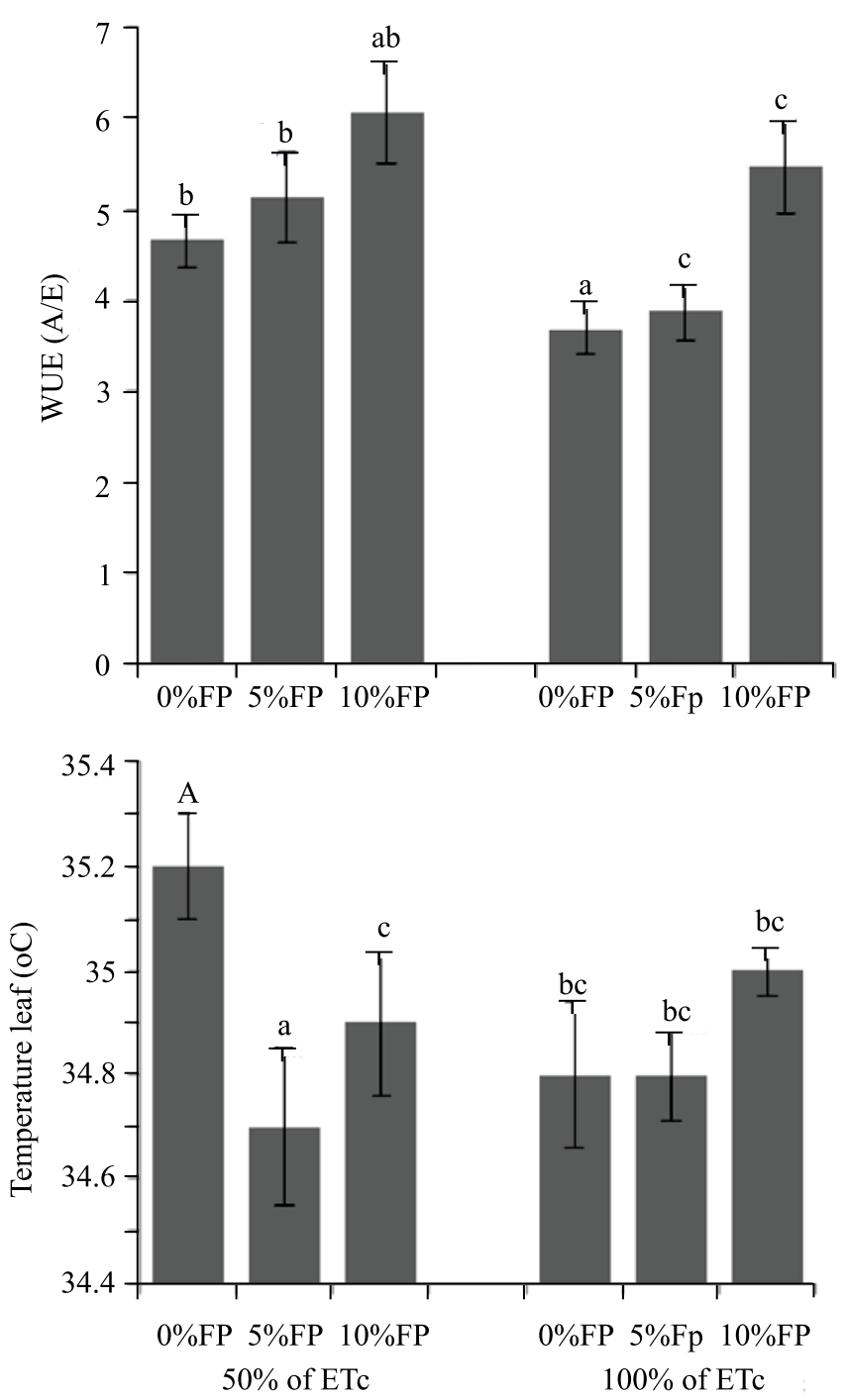

Figure 3. Intrinsic water-use efficiency (IWUE), instantaneous water-use efficiency (WUE), contents of chlorophyll a and b, and leaf temperature of cowpea plants (Vigna unguiculata) subjected to ETc replacements at 50 and $100 \%$, and to treatments with pulverized $\mathrm{CaO}$-based particle film (PF) at 0,5 , and 10 . Means followed by equal lowercases for different treatments do not differ, by Tuckey's test, at 5\% probability. 
reflected the excess light incidence under the leaves, which avoided a thermal and luminous stress and resulted in lower-stomatic closure and lower amounts of water for latent heat dissipation, culminating in lower transpiration and higher-instantaneous water use efficiency (WUE).

Besides the gas exchange, the chlorophyll content was also influenced by water restriction (Figure 3); and the application of the particle film affected the concentration of chlorophyll in the cowpea. The lowest levels of chlorophyll a and chlorophyll $\mathrm{b}$ were found in the control with $50 \% \mathrm{ETc}$, at 29.96 and 12.74, respectively. As observed in the present study, the water restriction interfered in the photosynthetic process and promoted changes in the gas exchange and chlorophyll content, and it is therefore an indicator of stress (Mohawesh \& Al-Absi, 2009). The treatment with reduction of water availability $(50 \%$ ETc $)$ showed a reduction of chlorophyll content of $15.3 \%$ for chlorophyll a, and $25.5 \%$ for chlorophyll $\mathrm{b}$, for plants not treated with $\mathrm{CaO}$ particle film. The $\mathrm{CaO}$ particle film affected the cowpea plants treated with $5 \%$ as much as $10 \%$ of the film. In other words, the film protects leaves from excess light and temperature, however, this protection may result in the formation of reactive oxygen species (ROS) that can damage plants due to the oxidation of photosynthetic pigments, membrane lipids, proteins and nucleic acids.

\section{Conclusions}

1. The CaO-based particle film is capable of protecting cowpea plants from the effect of water restriction, and excess light and temperature.

2. The application of $10 \% \mathrm{CaO}$ particle film to cowpea plants allows cowpea to maintain a high-photosynthetic $\mathrm{CO}_{2}$ assimilation, moderate transpiration, and greater water use efficiency, when plants are subjected to water restriction.

\section{Acknowledgments}

To Coordenação de Aperfeiçoamento de Pessoal de Nível Superior (Capes, Finance Code 001), to Conselho Nacional de Desenvolvimento Científico e Tecnológico (CNPq), and to Fundação de Apoio à Pesquisa e à Inovação Tecnológica do Estado de Sergipe (Fapitec), for financial support.

\section{References}

BASTOS, E.A.; RAMOS, H.M.M.; ANDRADE JUNIOR, A.S. de; NASCIMENTO, F.N. do; CARDOSO, M.J. Parâmetros fisiológicos e produtividade de grãos verdes do feijão-caupi sob déficit hídrico. Water Resources and Irrigation Management, v.1, p.31-37, 2012.

BOARI, F.; DONADIO, A.; PACE, B.; SCHIATTONE, M.I.; CANTORE, V. Kaolin improves salinity tolerance, water use efficiency and quality of tomato. Agricultural Water Management, v.167, p.29-37, 2016. DOI: https://doi.org/10.1016/j. agwat.2015.12.021.

BOARI, F.; DONADIO, A.; SCHIATTONE, M.I.; CANTORE, V. Particle film technology: A supplemental tool to save water. Agricultural Water Management, v.147, p.154-162, 2015. DOI: https://doi.org/10.1016/j.agwat.2014.07.014.

CANTORE, V.; PACE, B.; ALBRIZIO, R. Kaolin-based particle film technology affects tomato physiology, yield and quality. Environmental and Experimental Botany, v.66, p.279-288, 2009. DOI: https://doi.org/10.1016/j.envexpbot.2009.03.008.

CHAVARRIA, G.; DURIGON, M.R.; KLEIN, V.A.; KLEBER, H. Restrição fotossintética de plantas de soja sob variação de disponibilidade hídrica. Ciência Rural, v.45, p.1387-1393, 2015. DOI: https://doi.org/10.1590/0103-8478cr20140705.

CHAVES, M.M. Effects of water deficits on carbon assimilation. Journal of Experimental Botany, v.42, p.1-16, 1991. DOI: https:// doi.org/10.1093/jxb/42.1.1.

CUNHA, T.J.F.; SILVA, F.H.B.B. da; SILVA, M.S.L. da; PETRERE, V.G.; SÁ, I.B.; OLIVEIRA NETO, M.B. de; CAVAlCANTI, A.C. Solos do Submédio do Vale do São Francisco: potencialidades e limitações para uso agrícola. Petrolina: Embrapa Semiárido, 2008. 60p. (Embrapa Semiárido. Documentos, 211).

EL-KHAWAGA, A.S. Response of grand naine banana plants grown under different soil moisture levels to antitranspirants application. Asian Journal Crop Science, v.5, p.238-250, 2013. DOI: https://doi.org/10.3923/ajcs.2013.238.250.

FERREIRA, D.F. Sisvar: a computer statistical analysis system. Ciência e Agrotecnologia, v.35, p.1039-1042, 2011. DOI: https:// doi.org/10.1590/S1413-70542011000600001.

FREITAS, R.M.O. de; DOMBROSKI, J.L.D; FREITAS, F.C.L. de; NOGUEIRA, N.W.; PINTO, J.R. de S. Physiological responses of cowpea under water stress and rewatering in no-tillage and conventional tillage systems. Revista Caatinga, v.30, p.559-567, 2017. http://dx.doi.org/10.1590/1983-21252017v30n303rc.

GLENN, D.M. Effect of highly processed calcined kaolin residues on apple productivity and quality. Scientia Horticulturae, v.201, p.101-108, 2016. DOI: https://doi.org/10.1016/j.scienta.2016.01.035.

GLENN, D.M. The mechanisms of plant stress mitigation by kaolin-based particle films and applications in horticultural and agricultural crops. HortScience, v.47, p.710-711, 2012. DOI: https://doi.org/10.21273/HORTSCI.47.6.710.

GONÇALVES, J.R.P.; FONTES, J.R.A.; DIAS, M.C.; ROCHA, M.M.; FREIRE FILHO, F.R. BRS Guariba - nova cultivar de 
feijão-caupi para o estado do Amazonas. Manaus: Embrapa Amazônia Ocidental, 2009. 4p. (Embrapa Amazônia Ocidental. Comunicado Técnico, 76).

GONTIA, N.K.; TIWARI, K.N. Development of crop water stress index of wheat crop for scheduling irrigation using infrared thermometry. Agricultural Water Management, v.95, p.11441152, 2008. DOI: https://doi.org/10.1016/j.agwat.2008.04.017.

INMET. Instituto Nacional de Meteorologia. Available at: $<$ https:// http://www.inmet.gov.br/sonabra/pg_dspDadosCodigo_ sim.php?QTQwOQ==>. Accessed on: Dec. 152015.

LAWLOR, D.W.; TEZARA, W. Causes of decreased photosynthetic rate and metabolic capacity in water-deficient leaf cells: a critical evaluation of mechanisms and integration of processes. Annals of Botany, v.103, p.561-579, 2009. DOI: https:// doi.org/10.1093/aob/mcn244.

MANTOVANI, E.C.; BERNARDO, S.; PALARETTI, L.F. Irrigação: princípios e métodos. 3.ed. Viçosa: Ed. da UFV, 2009. $355 \mathrm{p}$.

MOHAWESH, O.E.; AL-ABSI, K.M. Physiological response of two apple genotypes to different water regimes under semiarid conditions. Advances in Horticultural Science, v.23, p.158-165, 2009.

OLIVEIRA, E.M. de; OLIVEIRA, R.A. de; SEDIYAMA, G.C.; CECON, P.R.; DRUMOND, L.C.D. Análise do coeficiente e o desempenho do irrigâmetro e a influência dos elementos do clima na estimativa da evapotranspiração. Engenharia na Agricultura, v.19, p.348-360, 2011. DOI: https://oi.org/10.13083/ reveng.v19i4.131.

OLIVEIRA, F.C.C.; PEDROTTI, A.; FELIX, A.G.S.; SOUZA, J.L.S.; HOLANDA, F.S.R.; MELLO JUNIOR, A.V. Características químicas de um Argissolo e a produção de milho verde nos Tabuleiros Costeiros sergipanos. Revista Brasileira de Ciências Agrárias, v.12, p.354-360, 2017. DOI: https://doi. org/10.5039/agraria.v12i3a5464.

PACE, B.; CANTORE, V. Colture in pien'aria, più difese col caolino. Colture Protette, v.38, p.75-82, 2009.

PARRY, M.A.J.; FLEXAS, J.; MEDRANO, H. Prospects for crop production under drought: research priorities and future directions. Annals of Applied Biology, v.147, p.211-226, 2005. DOI: https://doi.org/10.1111/j.1744-7348.2005.00032.x.

RIBEIRO, V.Q. (Ed.). Cultivo do feijão caupi (Vigna unguiculata (L) Walp). Teresina: Embrapa Meio-Norte, 2002, 108p. (Embrapa Meio-Norte. Sistemas de produção, 2).

SABOYA, R. de C.C.; BORGES, P.R.S.; SABOYA, L.M.F.; MONTEIRO, F.P. dos R.; SOUZA, S.E.A. de; SANTOS, A.F. dos; SANTOS, E.R. dos. Resposta do feijão-caupi a estirpes fixadoras de nitrogênio em Gurupi-TO. Journal of Biotechnology and Biodiversity, v.4, p.40-48, 2013.

SHELLIE, K.; GLENN, D.M. Wine grape response to kaolin particle film under deficit and well-watered conditions. Acta Horticulturae, v.792, p.587-592, 2008. DOI: https://doi. org/10.17660/ActaHortic.2008.792.69.

SHELLIE, K.C.; KING, B.A. Kaolin particle film and water deficit influence red winegrape color under high solar radiation in an arid climate. American Journal of Enology and Viticulture, v.64, p.214-222, 2013. DOI: https://doi.org/10.5344/ajev.2013.12067.

SILVA, P.S.O. da; OLIVEIRA JUNIOR, L.F.G.; GONZAGA, M.I.S.; SENA, E. de O.A.; MACIEL, L.B. dos S.; FIAES, M.P.; MATTOS, E.C. de; CARNELOSSI, M.A.G. Effects of calcium particle films and natural shading on ecophysiological parameters of conilon coffee. Scientia Horticulturae, v.245, p.171-177, 2019. DOI: https://doi.org/10.1016/j.scienta.2018.10.010.

SINGH, S.K.; REDDY, K.R. Regulation of photosynthesis, fluorescence, stomatal conductance and water-use efficiency of cowpea (Vigna unguiculata [L.] Walp.) under drought. Journal of Photochemistry and Photobiology B: Biology, v.105, p.40-50, 2011. DOI: https://doi.org/10.1016/j.jphotobiol.2011.07.001.

WANG, D.; GARTUNG, J. Infrared canopy temperature of early-ripening peach trees under postharvest deficit irrigation. Agricultural Water Management, v.97, p.1787-1794, 2010. DOI: https://doi.org/10.1016/j.agwat.2010.06.014.

WEERAKKODY, P.; JOBLING, J.; INFANTE, M.M.V.; ROGERS, G. The effect of maturity, sunburn and the application of sunscreens on the internal and external qualities of pomegranate fruit grown in Australia. Scientia Horticulturae, v.124, p.57-61, 2010. DOI: https://doi.org/10.1016/j.scienta.2009.12.003. 